\title{
Self-efficacy in volleyball: What has been evaluated? A systematic review
}

\section{Autoeficacia en voleibol: ¿Qué se ha evaluado? Una revisión sistemática}

\section{Autoeficácia no voleibol: O que se tem avaliado? Uma revisão sistemática}

\author{
Machado, T. A. ${ }^{1}$, Balaguer, $\mathrm{I}^{2}$, Paes, M. J ${ }^{1}$, Fernandes, G. J. ${ }^{3}$, Stefanello, J. M. F. ${ }^{1}$ \\ ${ }^{1}$ Federal University of Paraná (Brasil); ${ }^{2}$ Universitat de València (España); ${ }^{3}$ Technological Federal \\ University of Paraná (Brasil)
}

\begin{abstract}
Self-efficacy in sport has been the object of study in different modalities, including volleyball. The aim of the present study was to verify, by means of a systematic review, what has been evaluated in volleyball self-efficacy studies. The APA, PsycInfo, Bireme, Eric, Science Direct, Pubmed and Scopus databases were used to carry out the search. After the search, the articles were selected using the inclusion and exclusion criteria, resulting in 7 articles. The results point to a lack of clarity in the instruments for assessing self-efficacy in volleyball, with regard to the technical, tactical, physical or psychological attributes they are designed to measure. Few articles have described the psychometric properties of the instruments used, which imply, in practical terms, inaccurate results. It is suggested that specific instruments for the modality should be developed that present the statistical procedures used in order to obtain reliable results.
\end{abstract}

Palabras clave: performance, sport, athletes.

\section{RESUMEN}

La autoeficacia en el deporte ha sido motivo de estudio en diferentes modalidades, entre las que figura el voleibol. El objetivo del presente estudio fue realizar una revisión sistemática para conocer lo que se ha evaluado en los estudios sobre autoeficacia en voleibol. Las bases de datos utilizadas fueron APA PsycInfo, Bireme Eric, Science Direct, PubMed y Scopus. A partir de esta búsqueda, siguiendo los criterios de inclusión y exclusión se seleccionaron 7 artículos. Los resultados apuntan a la falta de claridad en los instrumentos de evaluación de la autoeficacia en el voleibol en lo referente a lo que pretenden medir de los atributos técnicos, tácticos, físicos o psicológicos. Además, pocos artículos indicaron las propiedades psicométricas de los instrumentos utilizados, lo que conduce, en términos prácticos, a resultados imprecisos. Se sugiere que se desarrollen instrumentos específicos para el voleibol y que en los artículos se presenten los procedimientos estadísticos utilizados.

Keywords: rendimiento, deporte, atletas.

\section{RESUMO}

A autoeficácia no esporte tem sido propósito de estudo com diferentes modalidades, entre elas o voleibol. O objetivo deste estudo de revisão sistemática foi verificar o que se tem avaliado sobre autoeficácia do voleibol. Utilizaram-se as bases de dados APA PsycInfo, Bireme, Eric, Science Direct, Pubmed e Scopus para efetuar as buscas. Após a pesquisa, os artigos foram selecionados, utilizando-se dos critérios de inclusão e exclusão, resultando em 7 artigos. Os resultados apontam falta de clareza nos instrumentos de avaliação da autoeficácia no voleibol quanto ao que pretendem medir em relação aos atributos técnicos, táticos, físicos ou psicológicos. Além disso, poucos artigos apresentaram propriedades psicométricas dos instrumentos utilizados, o que implica, em termos práticos, em resultados imprecisos. Sugere-se a construção de instrumentos específicos para a modalidade que apresentem procedimentos estatísticos utilizados a fim de obter resultados fidedignos.

Correspondence to: Thais do Amaral Machado. Programa de Pós Graduação em Educação Física. Rua Coração de Maria, 92, Jardim Botânico, Curitiba, PR- Brasil. Email: tha.thatha25@gmail.com 


\section{Self-efficacy in volleyball}

Palavras chave: desempenho, esporte e atletas.

\section{INTRODUCTION}

Since the first article published by Bandura on self-efficacy in 1977 within the framework of social cognitive theory, there has been great acceptance of this construct in different contexts, including the sport context. Specifically, although the self-efficacy construct was proposed by Bandura (1977) to address the treatment of anxiety in clinical psychology, selfefficacy has been an important research topic in the sport context (Balaguer, Escarti, \& Villamarín, 1995; Machado, Paes, Berbetz, \& Stefanello, 2014) with athletes from different competitive levels and modalities, such as freediving (Baretta, Greco, \& Steca, 2017), taekwondo (Estevan, Álvarez, \& Castillo, 2016), basketball (Lázaro \& Villamarín, 1993; Ortega, Olmedilla, Sainz de Baranda, \& Gómez, 2009; Ortega, Olmedilla, \& Cárdenas, 2007), golf (Irazusta \& Arruza, 2006; Rodriguez, López, Gómez, \& Rodríguez, 2015), tennis (Gónzalez, 2017), and football (García-Naveira, 2018; Leo, García-Calvo, Sanchez-Miguel, \& Parejo, 2008; Leo, García-Calvo, Sánchez-Miguel, \& de la Vega, 2011).

Self-efficacy is defined as one's belief about being able to perform a specific task successfully in order to obtain a certain outcome (Bandura, 1986). This construct refers to people's beliefs about what they think they can do with whatever skills they possess. These beliefs are not considered stable traits, but rather the product of a complex process of selfappraisal and self-persuasion originating from the cognitive processing of various sources of efficacy information. Specifically, the development of self-efficacy beliefs stems from four sources of information. Bandura (1997, 1986) referred to them as past performance accomplishments - which are related to previous experiences with tasks that require the same domain - vicarious experiences - which are related to the observation of tasks performed by others with a profile similar to that of the individual - verbal persuasion - which contemplates the feedback the individual receives, based on the conviction that $\mathrm{s} / \mathrm{he}$ has the necessary abilities to perform this action and physiological states - which can be an indicator of how the individual reacts to the expectation of accomplishing a task and his/her belief in the capacity to perform it -. These sources of information contribute to elaborating efficacy judgments, which have consequences on the levels of motivation (e.g., reflected in challenges, effort, and perseverance in the face of difficulties), thought patterns (e.g., causal 


\section{Machado, T. A., Balaguer, I., Paes, M. J. Fernandes, G. J., Stefanello, J. M. F.}

attributions), and emotional responses (e.g., pride, unhappiness).

To explain the relationship between selfefficacy beliefs and behavior, Bandura (1977, 1986) distinguished between self-efficacy expectations and outcome expectations. Outcome expectations are defined by Bandura as beliefs about the probability that this specific course of action will lead to certain consequences or outcomes, whereas self-efficacy expectations refer to beliefs about one's ability to execute a specific course of action. The former are related to one's environment (e.g., earning money), and the latter have to do with beliefs about one's competence (feeling capable). Although both self-efficacy expectations and outcome expectations can influence behavior in sport situations, Bandura (1986) argues that outcome expectations are highly dependent on self-efficacy judgments and, thus, do not add much to what is already predicted by self-efficacy expectations. Thus, self-efficacy expectations are postulated to have a more powerful influence on behavior (Bandura, 1977).

In the literature, self-efficacy expectations have been found to be robust, positive, and consistent predictors of sport performance (e.g., Balaguer et al., 1995; Feltz \& Magyar, 2006; Garcia-Naveira, 2018; Gilson, Chow, \& Feltz, 2012). As a predictor of athletes' performance, self-efficacy, when positive, may be a key driver in improving the performance of motor practice; when negative, it may raise doubts about one's capacity to perform. In addition, high self-efficacy indicates how persistent athletes will deal with obstacles, how motivated they will be when faced with adversities they may encounter, and the degree of effort they will make to achieve their goals (Feltz, Short, \& Sullivan, 2008).

Another important contribution of the theory of self-efficacy, central to the present study, is the measurement of self-efficacy proposed by Bandura (1977, 1997). Since the initial formulation of his theory, Bandura has defended the use of specific self-efficacy measures, rather than evaluations of overall performance expectations. The microanalytic approach proposed by Bandura (1977, 2006) requires the assessment of the level or magnitude, strength, and generality of selfefficacy beliefs. The level of self-efficacy refers to the number of activities individuals judge themselves to be capable of performing above a selected cutoff value of efficacy strength (Bandura, 1977, 1982). The strength of the belief in self-efficacy reflects how convinced a person is of his/her ability to perform a given task, and generality represents how self-efficacy beliefs are positively related, even when they lie in different domains (Bandura, 1977). In sum, 


\section{Self-efficacy in volleyball}

self-efficacy is not an overall trait, but rather a distinct group of self-beliefs related to different domains of functioning. There is no general measure of self-efficacy that encompasses all goals; instead, there are multidimensional measures capable of revealing the pattern and level of generalization of a person's self-efficacy (Vieira, 2012). A measure that addresses everything loses predictive and explanatory value, due to the lack of expression for the performance domain in question. Therefore, selfefficacy scales must be elaborated for the specific domain of the research area (Bandura, 1997).

Because Bandura argues that self-efficacy measurements must be specific to the task at hand, we consider that is important to review how self-efficacy has been evaluated in volleyball studies.

The International Volleyball Federation considers volleyball to be a competitive sport that requires high physical and technical performance, and it has been posited that the dynamism of this sport modality means that athletes have to adapt constantly to the new realities and train for better performance on the court (Fivb, 2017). Therefore, it is important to examine how these characteristics have been explored in the research. Specifically, it is important to discover which attributes (physical, technical, tactical, or psychological) have been included in the items of instruments designed to assess self-efficacy in volleyball studies.

In previous studies exploring the instruments used to measure self-efficacy related to sports performance, Machado et al. (2014) found that self-efficacy beliefs in volleyball were related to certain technical foundations (for example, the serve in volleyball), without duly clarifying how these aspects were evaluated. Although the objective of some of these studies was to analyze technical, tactical, physical, and psychological aspects, they did not offer satisfactory information about the self-efficacy approach used in the measurement of selfefficacy beliefs.

Thus, the present systematic review study aims to investigate how self-efficacy has been evaluated in the context of volleyball, and what indicators and attributes have been contemplated in the instruments used to evaluate this construct.

\section{MATERIAL AND METHODS}

\section{Sources}

We searched for articles in the following electronic databases: Scopus, Eric, APA PsycInfo, PubMed, Science Direct, and Bireme. The rationale for using these databases was that they include articles in the areas of health, psychology, and sport. 


\section{Machado, T. A., Balaguer, I., Paes, M. J. Fernandes, G. J., Stefanello, J. M. F.}

The search by keywords was carried out independently by the researchers, using the Boolean operator and the combination of the three following descriptors "self-efficacy" AND "volleyball” AND "performance. The search was conducted in English, Portuguese, and Spanish (although no article was found in the Spanish language that met the criteria). For the search, the descriptors were contemplated in the title, abstract, or keywords in the databases.

\section{Inclusion and exclusion criteria}

As inclusion criteria, we considered only articles with volleyball athletes from different competitive levels (athletes from child categories to elite athletes) that assessed self-efficacy beliefs related to performance indicators.

As exclusion criteria, articles that included recreational athletes (sporadically practicing the modality), articles that referred to self-efficacy, but did not evaluate it properly in the study, articles from systematic reviews, theses, dissertations, letters to the reader, books, book chapters, notes, abstracts, and non-original articles were not included.

Procedure

Figure 1 shows the steps followed in the systematic review performed in the present study. In the initial search, a total of 339 articles were found. In this search, the period of publication of these studies was not defined, in order to analyze how this construct has been evaluated over time. After searching in the six databases previously mentioned, and introducing the exclusion criteria, the following articles were removed: non-original articles (87), articles repeated in more than one database (13), articles that did not evaluate athletes from volleyball or included recreational athletes who sporadically played volleyball (32). After this first exclusion phase, other studies were excluded after reading the title (42) and abstract (109). Then, the 56 full-text articles were read, identifying 50 studies that did not specifically evaluate self-efficacy, but rather other psychological skills. The first search was conducted in January 2017, and it was updated in April 2018. In this time interval, only one study met the established criteria, and therefore it was added to the previous 6 articles in this systematic review. Thus, seven studies were maintained for analysis in the present systematic review.

\section{RESULTS}

The results for aspects related to the articles included in this review are presented in Table 1. Specifically, they are presented in terms of the article reference (number of paper identification, authorship, year of publication, 


\section{Self-efficacy in volleyball}

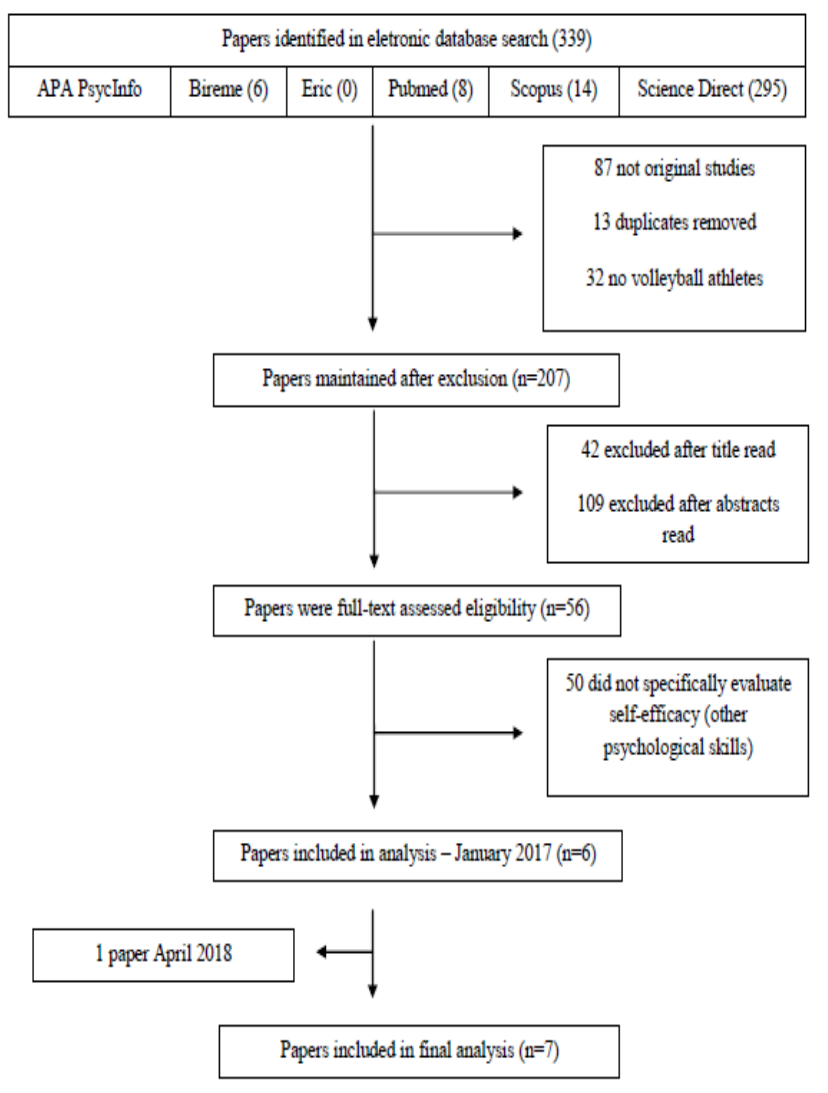

Figure 1 . Phases of the research to carry out the systematic review study.

journal in which the study was published, and a quality criterion), participants' characteristics (age, gender, and level), self-efficacy evaluation form (characteristics of the instrument and psychometric properties), type of self-efficacy measured (efficacy expectations and outcome expectations), and type of scale.

Considering the search period for this systematic review, the first article found was published in 1992, with no other publication on volleyball self-efficacy until 2008 (sixteen years later). As for the frequency of publication, 2012 is the year with the highest number of publications on the subject (three articles).

Regarding the quality criteria of the journals where the articles were published, six of them $(1,3,4,5$ and 6$)$ were published in journals in which it is possible to identify the journal impact factor (JCR) or classification according to the proposal in Qualis Capes (2013 - 2016). In only one of the studies (2), the quality criteria (JCR or Qualis) of the journal in which the article was published were not found. In addition, among the publications found, only two articles (2 and 3) had the same author.

Regarding the participants' characteristics, in two studies the participants were female (1 and 3), one study was carried out with male athletes (4), two with both sexes (2 and 7), and two did not report the participants' sex (5 and 6). Regarding the participants age, the mean was 21.16 years. With regard to the participants' months or years of experience in the modality of volleyball, two studies did not report this information ( 1 and 5). In the other studies, however, it ranged from 1.3 to 13.9 years, with an average of 10.34 years of experience.

When analyzing the way self-efficacy in volleyball athletes was evaluated, the results show that all seven of the studies reviewed used 
Machado, T. A., Balaguer, I., Paes, M. J. Fernandes, G. J., Stefanello, J. M. F.

Table 1. Article reference (number, authors, year of publication, journal, and quality criterion), participants' characteristics (age, gender, and level), evaluation form, type of self-efficacy expectations, and type of scale.

\begin{tabular}{|c|c|c|c|c|c|}
\hline $\begin{array}{c}\text { Number of } \\
\text { paper } \\
\text { identification }\end{array}$ & $\begin{array}{c}\text { Authors, Year, } \\
\text { Journal and } \\
\text { Quality } \\
\text { Criterion }\end{array}$ & $\begin{array}{l}\text { Participants Age, } \\
\text { Gender, Level, } \\
\text { Months or Years of } \\
\text { Experience }\end{array}$ & Evaluation Form & $\begin{array}{l}\text { Type of Self- } \\
\text { efficacy } \\
\text { Expectations }\end{array}$ & Type of Scale \\
\hline 1 & $\begin{array}{l}\text { Lox (1992) } \\
\text { Perceptual and } \\
\text { Motor Skills } \\
\text { (A2) }\end{array}$ & $\begin{array}{l}\text { Volleyball female } \\
\text { players }(n=52) \\
M_{\text {Age }}=19.60 \text { years } \\
(* * * \text { The study does } \\
\text { not show SD }) \\
\text { Experience not } \\
\text { reported }\end{array}$ & $\begin{array}{l}\text { An instrument developed by the } \\
\text { authors to evaluate self-efficacy in } \\
\text { volleyball. } \\
\text { Scale with six items to measure } \\
\text { athletes' perception of competence } \\
\text { in relation to volleyball } \\
\text { fundamentals, using a 9-point } \\
\text { Likert scale. } \\
\text { The scores were then averaged to } \\
\text { yield a total self-efficacy score, } \\
\text { with a possible range from } 1 \text { to } 9 \text {. }\end{array}$ & $\begin{array}{l}\text { Efficacy } \\
\text { Expectations }\end{array}$ & $\begin{array}{l}\text { Likert Scale } \\
9 \text { points }\end{array}$ \\
\hline 2 & $\begin{array}{c}\text { Zetou, Kourtesis, } \\
\text { Getsiou, } \\
\text { Michalopoulou, } \\
\& \\
\text { Kioumourtzoglo } \\
\text { (2008) } \\
\text { Athletic Insight: } \\
\text { The Online } \\
\text { Journal of Sport } \\
\text { Psychology } \\
\text { (Quality criterion } \\
\text { was not found) }\end{array}$ & $\begin{array}{l}\text { New Beach } \\
\text { Volleyball Players ( } \\
=32) \\
\mathrm{M}_{\mathrm{Age}}=12.80 ; S D= \\
0.53 \\
\text { Months } \\
\text { experience }=\mathrm{M}_{\mathrm{Age}}= \\
13.2 ; S D=0.20 \\
\text { National level } \\
\text { men and } 30 \text { women) } \\
\text { Student level (30 men } \\
\text { and 24 women) }\end{array}$ & $\begin{array}{l}\text { Specific instrument for evaluation } \\
\text { of self-efficacy in sports } \\
\text { (Theodorakis, 1996), composed of } \\
\text { five items to assess the basic } \\
\text { volleyball skills of "setting" and } \\
\text { "passing" } \\
\text { Following pre-testing for each skill, } \\
\text { the participants were informed of } \\
\text { their score, and they were asked to } \\
\text { fill out the self-efficacy } \\
\text { questionnaire, stating the possible } \\
\text { score they would try to reach. } \\
\text { The questionnaire included five } \\
\text { questions, and the participants had } \\
\text { to answer using a 10-point scale. }\end{array}$ & $\begin{array}{l}\text { Efficacy } \\
\text { Expectations }\end{array}$ & $\begin{array}{l}\text { Likert Scale } \\
10 \text { points }\end{array}$ \\
\hline
\end{tabular}




\section{Self-efficacy in volleyball}

\begin{tabular}{|c|c|c|c|c|c|}
\hline $\begin{array}{c}\text { Number of } \\
\text { paper } \\
\text { identification }\end{array}$ & $\begin{array}{c}\text { Authors, Year, } \\
\text { Journal and } \\
\text { Quality Criterion } \\
\end{array}$ & $\begin{array}{l}\text { Participants Age, Gender, } \\
\text { Level, Months or Years of } \\
\text { Experience } \\
\end{array}$ & Evaluation Form & $\begin{array}{l}\text { Type of Self- } \\
\text { efficacy } \\
\text { Expectations } \\
\end{array}$ & $\begin{array}{l}\text { Type } \\
\text { of } \\
\text { Scale }\end{array}$ \\
\hline 3 & $\begin{array}{l}\text { Zetou, Vernadakis, } \\
\text { Bebetsos, \& } \\
\text { Makraki (2012) } \\
\text { Journal of Human } \\
\text { Sport and exercise } \\
\text { (B1) }\end{array}$ & $\begin{array}{l}\text { Volleyball female athletes }(\mathrm{n}= \\
57) . \\
\mathrm{M}_{\text {Age }}=12.83 ; S D=0.97 \text { years. } \\
\text { Years of experience } \mathrm{M}_{\text {Age }}= \\
1.99 ; S D=0.67\end{array}$ & $\begin{array}{l}\text { Specific instrument for evaluating self-efficacy in } \\
\text { sports (Theodorakis, 1996). } \\
\text { Service Performance - three times. Participants were } \\
\text { informed of their performance scores on the service } \\
\text { test, and then they indicated their expectation of self- } \\
\text { efficacy by responding to question such as "On this } \\
\text { specific service test, I can achieve a score of...". they } \\
\text { indicated the magnitude of self-efficacy by replying to } \\
\text { the question "How certain you are?" on a 10-point } \\
\text { scale anchored by "absolutely certain" (10) and } \\
\text { "uncertain" (1). Subject rated their self-efficacy } \\
\text { estimations for performance levels ranging from } 10 \text { to } \\
40 \text {. } \\
\text { Cronbach's alpha values of .76; .89, and .81 for the } \\
\text { three times measured, respectively. }\end{array}$ & $\begin{array}{l}\text { Efficacy } \\
\text { Expectations }\end{array}$ & $\begin{array}{l}\text { Likert } \\
\text { Scale } \\
10 \\
\text { points }\end{array}$ \\
\hline 4 & $\begin{array}{l}\text { Gomes, Miranda, } \\
\text { Filho, \& Brandão } \\
\qquad(2012) \\
\text { Journal of Physical } \\
\text { Education/UEM } \\
\text { (B1) }\end{array}$ & $\begin{array}{l}-1 \text { st stage }=9 \text { athletes mean age } \\
=23.78 ; \mathrm{SD}=3.86 \text { and years of } \\
\text { experience: } \mathrm{M}_{\mathrm{Age}}=10 \text { years; } \\
S D=6.21 \\
-2 \mathrm{nd} \text { stage }=11 \text { athletes } \mathrm{M}_{\mathrm{Age}}= \\
24.36 ; S D=3.13 \text { and years of } \\
\text { experience: } \mathrm{M}_{\mathrm{Age}}=11 \text { years, } \\
S D=5.34 \\
-3 \mathrm{rd} \text { stage } 10 \text { athletes } \mathrm{M}_{\mathrm{Age}}= \\
22.80 ; S D=3.58 \text { and years of } \\
\text { experience: } \mathrm{M}_{\text {Age }}=11.1 \text { years; } \\
S D=5.99 . \text { All male athletes } \\
\text { competed at varying levels } \\
\text { (regional, national and } \\
\text { international). }\end{array}$ & $\begin{array}{l}\text { Self-efficacy Scale for Volleyball (EAIV) (Carmo, } \\
\text { 2006), adapted from "Hockey Team Confidence } \\
\text { Survey" ( Feltz \& Lirgg, 1998). } \\
\text { Questionnaire composed of eight items, rated on a 11- } \\
\text { point Likert scale. } \\
\text { The athlete is asked about the degree of confidence in } \\
\text { his/her ability to perform important skills in the game. }\end{array}$ & $\begin{array}{l}\text { Efficacy } \\
\text { Expectations }\end{array}$ & $\begin{array}{l}\text { Likert } \\
\text { Scale } \\
11 \\
\text { points }\end{array}$ \\
\hline
\end{tabular}


Machado, T. A., Balaguer, I., Paes, M. J. Fernandes, G. J., Stefanello, J. M. F.

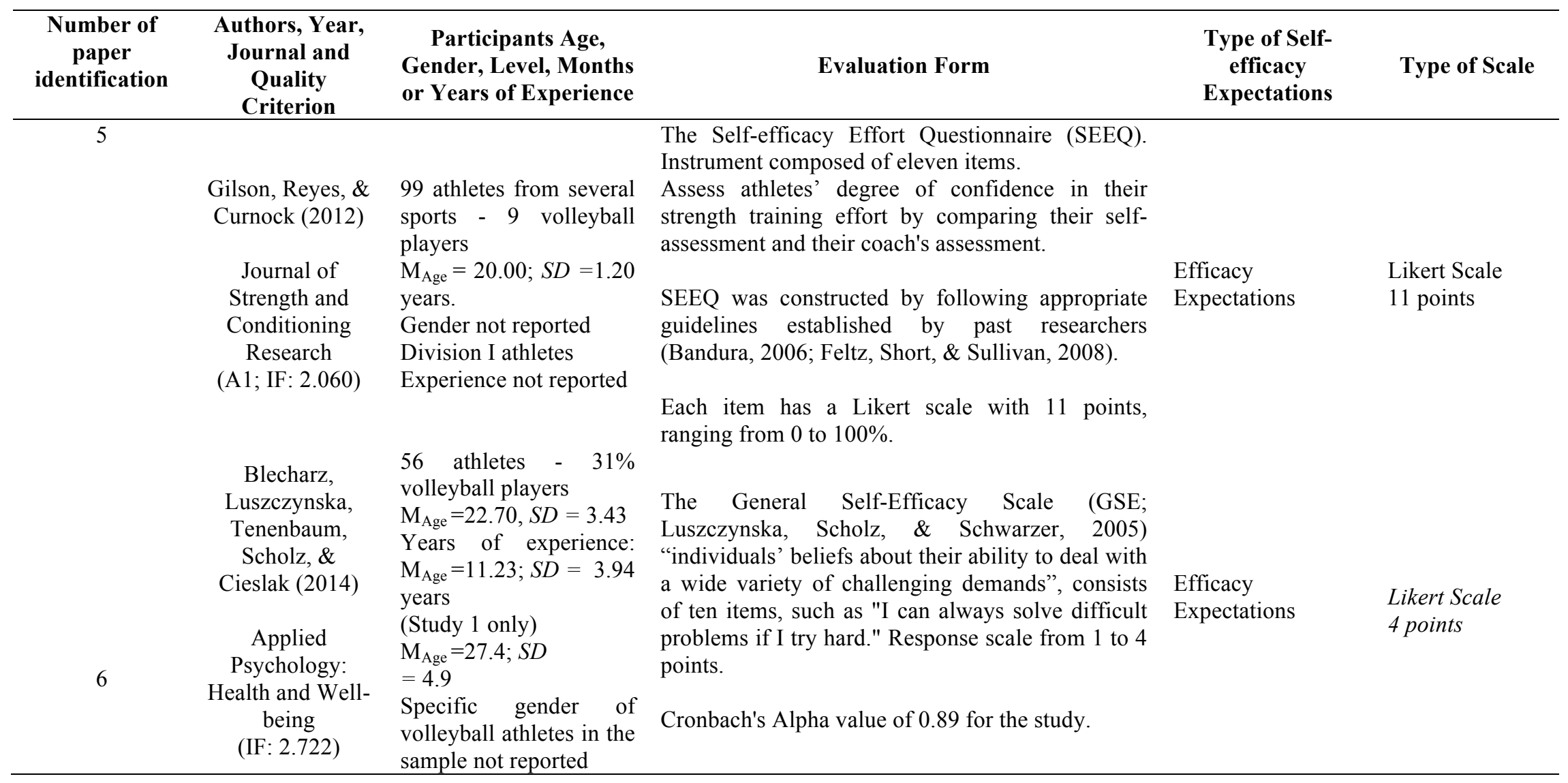




\section{Self-efficacy in volleyball}

\begin{tabular}{|c|c|c|c|c|c|}
\hline $\begin{array}{c}\text { Number of } \\
\text { paper } \\
\text { identification }\end{array}$ & $\begin{array}{c}\text { Authors, Year, } \\
\text { Journal and } \\
\text { Quality } \\
\text { Criterion } \\
\end{array}$ & $\begin{array}{l}\text { Participants Age, } \\
\text { Gender, Level, Months } \\
\text { or Years of Experience }\end{array}$ & Evaluation Form & $\begin{array}{l}\text { Type of Self- } \\
\text { efficacy } \\
\text { Expectations }\end{array}$ & Type of Scale \\
\hline 7 & $\begin{array}{c}\text { Guicciardi, } \\
\text { Fadda, \& Delitala } \\
\text { (2016) } \\
\\
\text { International } \\
\text { Journal of Sport } \\
\text { Psychology } \\
\text { (A2) } \\
\text { (IF: } 0.871)\end{array}$ & $\begin{array}{l}133 \text { volleyball players } \\
64 \text { males and } 69 \text { females } \\
\mathrm{M}_{\text {Age }}=25.34 ; S D=5.48 \\
\text { Years of experience: } \\
\mathrm{M}_{\text {Age }}=13.9 ; S D=5.22 \\
\text { years }\end{array}$ & $\begin{array}{l}\text { The Volleyball Multidimensional } \\
\text { Self-efficacy Scale (V-MSES; } \\
\text { Guicciardi, Fadda, \& Delitala, } \\
\text { 2016) investigates self-efficacy, } \\
\text { asking players to assess the } \\
\text { degree of confidence they have in } \\
\text { their ability to perform a specific } \\
\text { task. } \\
\text { Questionnaire composed of } 10 \\
\text { items, on a 5-point Likert scale. } \\
\text { (from } 1 \text { not confident to } 5= \\
\text { completely confident). } \\
\text { Cronbach's Alpha value of } 0.86 \\
\text { for the Regulation of emotions } \\
\text { and } 0.69 \text { for Communication. } \\
\text { Confirmatory Factor Analyses } \\
\text { V-MSES discriminates between } \\
\text { elite and non-elite athletes } \\
\text { Correlations between the V- } \\
\text { MSES and task and ego } \\
\text { orientation }\end{array}$ & & $\begin{array}{l}\text { Likert Scale } \\
5 \text { points }\end{array}$ \\
\hline
\end{tabular}




\section{Machado, T. A., Balaguer, I., Paes, M. J. Fernandes, G. J., Stefanello, J. M. F.}

questionnaires. One of the studies (1) used a questionnaire to assess the perception of competence in order to measure self-efficacy; three studies (1, 4 and 7) used specific instruments for volleyball, although only one of them was designed specifically for this modality (7); and three (5, 2 and 3) used questionnaires for the sports context. Only one study used a questionnaire to assess overall self-efficacy (6).

Regarding the evaluation form of the instruments used to measure self-efficacy, all were standardized questionnaires. Three studies reported Cronbach's alphas (3, 6 and 7), considered one of the most important psychometric properties for the reliability of the instrument. It should be noted that the other four studies (1, 2, 4 and 5) did not indicate the use of statistical procedures that reported psychometric properties of the instruments used to measure self-efficacy, and they did not present the instruments in their entirety.

With regard to the type of self-efficacy, that is, Bandura's distinction between selfefficacy expectations (the person's belief in his or her self-confidence to carry out a specific behavior) and outcome expectations (the belief that carrying out a specific behavior will lead to a given outcome), all the studies included in the review evaluated self-efficacy expectations.

In terms of the inclusion of the three microanalytic dimensions designed by Bandura
(2006) in the studies, that is, the level or magnitude (number of tasks you think you can perform), strength (degree of certainty with which you expect to achieve success at each level), or generality (number of domains in which the individual is considered effective), these characteristics were not clearly specified in the articles reviewed. Only the articles by Zetou et al. (2008, 2012), which used the Theodorakis questionnaire (1996), seemed to evaluate both magnitude and strength, although this aspect is not clearly defined.

Regarding the type of scale used to assess self-efficacy, only two articles (5 and 7) take into account the recommendations of Bandura (2006). What is evident in the articles is the need to specify the modality evaluated in the construction of the instrument (7) and use an 11point scale, ranging from 0 to $100 \%(5)$. The other 5 articles (1, 2, 3, 4 and 6) used Likert scales to assess self-efficacy, varying the number of points on the scale (Table 1).

In the reviewed articles, we also tried to identify indicators and attributes contemplated in the instruments used to evaluate self-efficacy in the specific context of volleyball. The first two columns of table 2 include the identification of the paper (identification number of the paper and authors and year of publication), followed by correlates of self-efficacy and intervention strategies, self-efficacy indicators, and attributes 


\section{Self-efficacy in volleyball}

of self-efficacy (technical, tactical, physical, and psychological).

Regarding the attributes related to selfefficacy, it was observed that in the volleyball modality, psychological aspects (one study, 6), physical aspects (one study, 5), technical aspects (four studies, 1, 2, 3, and 4) and (one study, 7) technical/tactical, regulation of emotions and motivation to practice and communication were evaluated. The main indicators of the skills related to the practice of volleyball (reception, digging, service, attack, block, defense) were also observed.

With regard to the methodologies used to evaluate self-efficacy in volleyball, four studies $(1,4,5$ and 6) used a cross-sectional research method to evaluate self-efficacy related to other psychological constructs (anxiety, selfconfidence, motivational climate, among others); two studies (2 and 3) were longitudinal studies with interventions (self-report and selfmodeling); and one study (7) presented the validation of an instrument to assess volleyball self-efficacy.

\section{DISCUSSION}

The aim of the present study was to investigate how self-efficacy has been evaluated in the context of volleyball, and what indicators and attributes have been contemplated in the instruments used to evaluate this construct.
The predominance of studies with female athletes can be highlighted, indicating that women have become the focus of research in recent years (Devide et al., 2011). This prevalence can be explained by the fact that women's participation in sports competitions has increased, as can be seen in the last Olympic Games, Rio 2016, where $45 \%$ of the athletes were female, revealing the balanced participation between the sexes (Ioc, 2016).

It was also observed a predominance of studies performed with experienced athletes (average of 10 years of experience). It is worth noting that the perception of self-efficacy is influenced by the previous experiences of the athletes and by their vicarious experiences (Bandura, 1997). Therefore, it has been suggested that this belief is stronger in more experienced athletes. A study with highperformance volleyball teams of both sexes (Machado, 2018) found that the most experienced athletes $(12.55 \pm 2.71$ years of experience in the sport) had strong self-efficacy before, during, and after the competition.

Regarding the instruments, only one validation study of a self-efficacy assessment instrument for elite and non- elite volleyball athletes was found, presenting some psychometric properties (Guicciardi et al., 2016). 
Machado, T. A., Balaguer, I., Paes, M. J. Fernandes, G. J., Stefanello, J. M. F.

Table 2. Evaluation, intervention strategies, indicators, and attributes of self-efficacy in volleyball.

\begin{tabular}{|c|c|c|c|c|}
\hline $\begin{array}{c}\text { Number of } \\
\text { paper } \\
\text { identification } \\
\end{array}$ & Authors, year & $\begin{array}{l}\text { Self-efficacy correlates/ } \\
\text { intervention strategies }\end{array}$ & Self-efficacy indicators & $\begin{array}{l}\text { Attributes of self- } \\
\text { efficacy }\end{array}$ \\
\hline 1 & Lox, 1992 & $\begin{array}{l}\text { Analysis of the relationship } \\
\text { between perceived competence, } \\
\text { anxiety, self-confidence and } \\
\text { self-efficacy. }\end{array}$ & $\begin{array}{lr}\text { Perception } & \text { of } \\
\text { competence } & \text { for } \\
\text { execution of blocking, } \\
\text { defense, reception, } \\
\text { digging, attack, and } \\
\text { service. }\end{array}$ & $\begin{array}{l}\text { Technician } \\
\text { (Block, defense, } \\
\text { reception, digging, } \\
\text { attack, and service) }\end{array}$ \\
\hline 2 & $\begin{array}{l}\text { Zetou et al., } \\
2008\end{array}$ & $\begin{array}{l}\text { Intervention study (pre and } \\
\text { post-test model) to evaluate the } \\
\text { effect of self-modeling on self- } \\
\text { efficacy of reception and } \\
\text { digging. }\end{array}$ & $\begin{array}{l}\text { Should indicate what } \\
\text { score they would achieve } \\
\text { and then whether or not } \\
\text { they are sure about their } \\
\text { answer. }\end{array}$ & $\begin{array}{l}\text { Technical (digging and } \\
\text { reception skills) }\end{array}$ \\
\hline 3 & $\begin{array}{l}\text { Zetou et al. } \\
\quad 2012\end{array}$ & $\begin{array}{l}\text { Intervention study (pre and } \\
\text { post-test model) to evaluate the } \\
\text { effect of the self-report on the } \\
\text { self-efficacy of the service. }\end{array}$ & $\begin{array}{l}\text { Self-confidence in } \\
\text { performing the service } \\
\text { execution technique. }\end{array}$ & $\begin{array}{l}\text { Technical (Execution of } \\
\text { the service); } \\
\text { Psychological } \\
\text { (Cognitive, due to the } \\
\text { technique of self- } \\
\text { modeling used) }\end{array}$ \\
\hline 4 & $\begin{array}{l}\text { Gomes et al., } \\
2012\end{array}$ & $\begin{array}{l}\text { Analysis of the relationship } \\
\text { between flow, motivational } \\
\text { orientation, } \\
\text { Self-efficacy, and perceived } \\
\text { ability. }\end{array}$ & $\begin{array}{l}\text { Degree of confidence } \\
\text { that the athlete is able to } \\
\text { perform skills that are } \\
\text { important for the game. }\end{array}$ & $\begin{array}{l}\text { Technicians (service, } \\
\text { digger, reception, } \\
\text { defense, attack, block). } \\
\text { Tactics (force opponent } \\
\text { errors) } \\
\text { Psychological (recover } \\
\text { from bad performances, } \\
\text { defeat opponents) }\end{array}$ \\
\hline 5 & $\begin{array}{l}\text { Gilson et al., } \\
2012\end{array}$ & $\begin{array}{l}\text { Relationship between self- } \\
\text { efficacy and effort in strength } \\
\text { training }\end{array}$ & $\begin{array}{l}\text { The degree of } \\
\text { confidence the athlete } \\
\text { has in his/her strength } \\
\text { training effort, } \\
\text { comparing his/her self- } \\
\text { assessment and the } \\
\text { coach's assessment. }\end{array}$ & Physical \\
\hline 6 & $\begin{array}{l}\text { Blecharz et } \\
\text { al., } 2014\end{array}$ & $\begin{array}{l}\text { Analysis of the relationship } \\
\text { between general self-efficacy } \\
\text { and motivational climate }\end{array}$ & $\begin{array}{l}\text { Generalized perception } \\
\text { of self-efficacy. Example } \\
\text { item: "I can always solve } \\
\text { difficult problems if I } \\
\text { work hard enough." }\end{array}$ & Psychological \\
\hline 7 & $\begin{array}{l}\text { Guicciardi et } \\
\text { al., } 2016\end{array}$ & $\begin{array}{l}\text { Validate the volleyball self- } \\
\text { efficacy scale in elite and non- } \\
\text { elite volleyball athletes using a } \\
\text { confirmative approach. } \\
\text { To verify with confirmatory } \\
\text { factor analyses the } \\
\text { multidimensional structure. } \\
\text { To verify that the scale } \\
\text { discriminates between elite and } \\
\text { non-elite athletes. } \\
\text { To explore correlations of the } \\
\text { scale with task and ego } \\
\text { orientation }\end{array}$ & $\begin{array}{l}\text { Assess the degree of } \\
\text { confidence they have in } \\
\text { their ability to perform a } \\
\text { specific task. }\end{array}$ & $\begin{array}{l}\text { Technical/Tactical } \\
\text { Regulation of emotions } \\
\text { Communication } \\
\text { Motivation to practice }\end{array}$ \\
\hline
\end{tabular}




\section{Self-efficacy in volleyball}

Two studies reported the Cronbach's alpha values, and these values are specific to the studies in question (Zetou et al., 2012), whereas no values were included from the validation study of the instrument used (Blecharz et al., 2014). This is a recurrent factor in several studies, and the authors end up presenting only the validity of the data obtained with the measurement instrument specifically in their study, but not the value originally obtained in the study on the elaboration and validation of the instrument, thus affecting reproducibility and comparisons between studies (Machado et al., 2014).

A possible explanation for the few studies found in this review may be associated with the year in which the Guide for the Construction of Self-efficacy

Scales was published (Bandura, 2006). The Guide presents parameters that support the conceptual and empirical analysis of the construct in question, highlighting the need

to consider different domains of self-efficacy functionality and the context in which this construct will be evaluated (Bandura, 2012). Therefore, the lack of these parameters in publications prior to this date can be understood.

In addition, most of the studies reviewed $(1,2,3,4,6,7)$ used, as a priority, measures that indicate the degree of efficacy evaluated on a Likert scale. Only one of these articles (5) evaluated the magnitude of selfefficacy. Bandura (2012) strongly criticizes the use of Likert scales to evaluate self-efficacy because this type of scale is appropriate for phenomena that have positive and negative valences, such as attitudes, opinions, and likes and dislikes, but not self-efficacy because a complete disability judgment (0) does not have a negative gradation. Bipolar self-efficacy scales with negative gradations below zero do not make sense. For the discontinuous bipolar scale score, there are studies that convert partially ordered positive and negative segments separated by neutral ones (do not agree or disagree) as if they were a completely ordered unipolar graduation. It does not make sense to say that you have a neutral level of self-efficacy. When ratings on a bipolar scale are converted to a unipolar ordinal scale, the significance of the neutral midpoint is rebuilt as a moderate level of self-efficacy. Thus, bipolar Likert-type scales that have been used to measure self-efficacy have had a distorted meaning (Bandura, 2012).

Although the reviewed studies did not specify the type and measure of self-efficacy assessed, it can be assumed that the majority sought to assess expectations of personal effectiveness, which refers to the athlete's belief in his/her ability to take the necessary steps to 


\section{Machado, T. A., Balaguer, I., Paes, M. J. Fernandes, G. J., Stefanello, J. M. F.}

achieve a goal.

Regarding the attributes related to selfefficacy, only one study evaluated technical, tactical, psychological, and communication aspects in volleyball, and four studies evaluated only technical aspects, with an emphasis on skills related to volleyball practice (passing, arming, serving, setting, blocking, defense). Therefore, the evaluation of psychological aspects was hardly explored, which may be a limitation of the studies contemplated in this systematic review.

There is a common misconception that the theory of self-efficacy is confined to measures of "narrow" tasks, where individuals judge the effectiveness of their specific performance on a specific task. However, the task has been defined as "work" that encompasses a wide range of activities, and not just isolated work, so that the strength of selfefficacy must be measured in a wide range of performances within an area of activity, and not only related to specific item performance (Bandura, 2012).

Among the psychological aspects evaluated, cross-sectional studies that associate self-efficacy with self-confidence constructs, motivational climate, and anxiety are highlighted. Self-efficacy acts in a way that cognitively regulates anxiety because of the strong perceived efficacy in controlling one's thoughts, and athletes may become less overwhelmed by negative thoughts and feel a lower level of anxiety (Bandura, 1982).

As for longitudinal studies with interventions, it is worth highlighting the studies in which self-report and self-report practices were used to improve and maintain athletes' sport self-efficacy, which can help athletes to have information not only in difficult times of practicing their modality, but also throughout their entire sport career.

It is important to mention, as a limitation of the study, that the low number of articles for analysis made it difficult to assess the selfefficacy attributes because most of the studies used non-specific tools to evaluate the construct in the context of the evaluated modality, especially with regard to the type of measurement scale used to measure self-efficacy (Likert 4 to 11 points), instead of a strength scale ( 0 to $100 \%$ ), as recommended by Bandura (2006).

\section{PRACTICAL APPLICATION}

Based on the results of this study, it is clear that it is necessary to develop specific instruments to assess self-efficacy in volleyball. There is a need for the production and reproduction of studies with volleyball athletes of different categories and both sexes, in order to have greater scientific evidence about the role of self-efficacy in sports practice. 


\section{Self-efficacy in volleyball}

The importance of psychometrics in the sporting context should be emphasized, in terms of the elaboration of instruments that contemplate technical, physical, tactical, and psychological aspects, in order to have a holistic view of the self-efficacy beliefs that are relevant to the athlete's performance.

The lack of instruments specifically designed to measure self-efficacy in volleyball is a difficulty that makes the evaluation of this variable imprecise and hard to reproduce.

Because we already know how selfefficacy in volleyball has been evaluated, and that there are limitations in the evaluation of this construct, it is important to develop instruments to evaluate this construct in this modality. In practical terms, volleyball athletes need to selfregulate during matches because several cognitive, emotional, and behavioral reactions are produced during the game, and to be successful, the perception of self-efficacy can contribute significantly to adapted selfregulation.

\section{Acknowledgment}

Thanks to Capes Foundation within the Ministry of Education, Brazil, for the scholarship granted n. BEX 88881.134897/2016-01.

\section{REFERENCIAS}

Balaguer, I., Escartí, A., \& Villamarín, F. (1995). Autoeficacia en el Deporte y en la actividad física: estado actual de la investigación. Revista de Psicología General y Aplicada, 48(1), 139-159.

Bandura, A. (1977). Social learning theory. Englewood Cliffs, NJ: Prentice Hall.

Bandura, A. (1982). Self-efficacy mechanism in human agency. American Psychologist, 37, $122-147$.

Bandura, A. (1986). Social foundations of thought and action: A social cognitive theory. (N. Prentice-Hall., Ed.). Englewood Cliff.

Bandura, A. (1997). Self-efficacy: The exercise of control. New York:

Freeman: W.H.

Bandura, A. (2006). Guide for constructing selfefficacy scales. In F. Pajares \& T. Urdan (Eds.), Self-efficacy beliefs of adolescents (5th ed.) (pp. 307-337). Greenwich: CT: Information Age Publishing.

Bandura, A. (2012). On the functional properties of Perceived Self-Efficacy Revisited. Journal of Management, 38(1), 9-44. doi: 10.1177/0149206311410606

Baretta, D., Greco, A., \& Steca, P. (2017). Understanding performance in risky sport: The role of self-efficacy beliefs and sensation seeking in competitive freediving. 


\section{Machado, T. A., Balaguer, I., Paes, M. J. Fernandes, G. J., Stefanello, J. M. F.}

Personality and Individual Differences, 117, 161-165. doi:

10.1016/j.paid.2017.06.006

Blecharz, J., Luszczynska, A., Tenenbaum,

G., Scholz, U., \& Cieslak, R. (2014).

Self-efficacy moderates but collective efficacy mediates between motivational climate and athletes' well-being. Applied Psychology: Health and Well-Being, 6(3), 280-299. doi: 10.1111/aphw.12028

Devide, F. P., Osborne, R., Silva, E. R.,

Ferreira, R. C., Clair, E. S., \& Nery, L. C. (2011). Estudos de gênero na Educação Física Brasileira. Motriz. Revista Da Educação Física, 7(1), 93-103. https://doi.org/10.5016/1980-

$6574.2011 v 17 \mathrm{n} 1 \mathrm{p} 93$

Estevan, I., Álvarez, O., \& Castillo, I. (2016). Autoeficacia percibida y rendimiento técnico-táctico en taekwondistas universitarios. Cuadernos de Psicología del Deporte, 16(2), 51-64.

Feltz, D. L., \& Lirgg, C. D. (1998). Perceived team and player efficacy in hockey. Journal of Applied Psychology, 4(83), 557-564.

Feltz, D. L., \& Magyar, M. T. (2006). Selfefficacy and adolescents in sport and physical activity. In F. Pajares \& T. Urdan (Eds.), Self-efficacy beliefs of adolescents (pp.161-179). Greenwich, CT: Information Age Publishing.
Feltz, D. L., \& Lirgg, C. D. (1998). Perceived team and player efficacy in hockey. Journal of Applied Psychology, 4(83), 557-564.

Feltz, D. L., \& Magyar, M. T. (2006). Selfefficacy and adolescents in sport and physical activity. In F. Pajares \& T. Urdan (Eds.), Self-efficacy beliefs of adolescents (pp.161-179). Greenwich, CT: Information Age Publishing.

Feltz, D. L., Short, S. E., \& Sullivan, P. J. (2008). Self-Efficacy in Sport: Research and strategies for working with athletes, teams, and coaches. International Journal of Sports Science and Coaching, 3(2), 293295. doi: 10.1260/174795408785100699

Fivb. (2017). International Volleyball Federation. Retrieved from http://www.fivb.com/

García-Naveira, A. (2018). Autoeficacia y rendimiento en jugadores de fútbol.

Cuadernos de Psicología del Deporte, $18(2), 68-79$.

Gilson, T. A., Reyes, G. F. C., \& Curnock, L. E. (2012). An examination of athletes' selfefficacy and strength training effort during an entire off-season. Journal of Strength and Conditioning Research, 26(2), 443451. doi: $10.1519 /$ jsc.0b013e3182254080

Gilson, T. A., Chow, G. M., \& Feltz, D. L. (2012). Self-Efficacy and Athletic Squat Performance: Positive or Negative 


\section{Self-efficacy in volleyball}

Influences at the Within- and BetweenLevels of Analysis. Journal of Applied Social Psychology, 42(6), 1467-1485. https://doi.org/10.1111/j.1559-

\subsubsection{8.x}

Gomes, S. S., Miranda, R., Filho, M. G. B., \& Brandão, M. R. F. (2012). O fluxo no voleibol: relação com a motivação, autoeficácia, habilidade percebida e orientação às metas. Revista Da Educação Física/UEM, 23(3), 379-387. doi: 10.4025/reveducfis.v23i3.17024

González Hernández, J. (2017). Diseño del entrenamiento mental del tenista. De lo científico a lo aplicado. Revista de Psicología Aplicada al Deporte y al Ejercicio Físico, 1(e5), 1-14. https://doi.org/10.5093/rpadef2017a1

Guicciardi, M., Fadda, D., \& Delitala, L.

(2016). A new multidimensional scale for measuring self-efficacy beliefs in volleyball. International Journal of Sport Psychology, 47, 13-25. doi: 10.7352/IJSP.2016.47.013.

Ioc. (2016). International Olympic Committee. Retrieved from https://www.olympic.org/ Irazusta, S., \& Arruza, J. (2006). Influencia de variables psicológicas en el rendimiento de jugadores amateurs de golf. Revista de Psicología del Deporte, 15(1), 127-138.
Lázaro, I., \& Villamarín, F. (1993). Capacidad predictiva de la autoeficacia individual y colectiva sobre el rendimiento en jugadores de baloncesto. Revista de Psicología del Deporte, 4, 27-38.

Leo, F., García-Calvo, T., Sánchez-Miguel, P., \& Parejo, I. (2008). Importancia de la percepción de eficacia para la mejora de la cohesión en el fútbol. Cuadernos de Psicología del Deporte, 8(1), 47-60.

Leo, F., García-Calvo, T., Sánchez-Miguel, P., \& de la Vega R. (2011). Relación entre la cohesión de equipo, la eficacia percibida y el rendimiento en equipos masculinos de jóvenes futbolistas. Revista Iberoamericana de Psicología del Ejercicio y el Deporte, 6(1), 47-62.

Lox, C. L. (1992). Perceived threat as a cognitive component of state anxiety and confidence. Perceptual and Motor Skills, 75(3 Pt 2), 1092-1094. doi: 10.2466/pms.1992.75.3f.1092

Luszczynska, A., Scholz, U., \& Schwarzer, R. (2005). The General Self-Efficacy Scale: Multicultural Validation

Studies. The Journal of Psychology, 139(5), 439-457. doi: 10.3200/JRLP.139.5.439-457 Machado, T. do A., Paes, M. J., Berbetz, S. R., \& Stefanello, J. M. F. (2014). Autoeficácia esportiva: uma revisão integrativa dos instrumentos de medida. Revista Da 


\section{Machado, T. A., Balaguer, I., Paes, M. J. Fernandes, G. J., Stefanello, J. M. F.}

Educação Física/UEM, 25(2), 323-333. doi: 10.4025/reveducfis.v25i2.21685.

Machado, T. do A. (2018). Autoeficácia de atletas de voleibol de alto rendimento. Tese de doutorado, Universidade Federal do Paraná, Brasil.

Ortega, E., Olmedilla, A., \& Cárdenas, D. (2007). La participación activa como base fundamental para la mejora del lanzamiento en baloncesto de formación. Revista de Ciencias del Ejercicio y la Salud®, 5(1), 18. doi: doi.org/10.15517/pensarmov.v5i1.355

Ortega, E., Olmedilla, A., Sainz de Baranda, P., \& Gómez, M.A. (2009). Relationship between the level of self-efficacy, performance indicators, and participation in youth basketball. Revista de Psicología del Deporte, 18(suppl), 337-342.

Rodríguez, M. C., López E., Gómez, P. G., \& Rodríguez, L. (2015). Programa de entrenamiento en control de la activación, rendimiento y autoeficacia en golfista infantiles. Un estudio de caso. Revista Iberoamericana de Psicología del Ejercicio $y$ el Deporte, 10(1), 77-84. Retrieved from https://dialnet.unirioja.es/servlet/articulo?co digo $=4926212$

Theodorakis, Y. (1996). The influence of goals, commitment, self-efficacy and selfsatisfaction on motor performance. Journal of Applied Sport Psychology, 8(2), 171182. doi.org/10.1080/10413209608406475

Vieira, D. A. (2012). Transição do ensino superior para o trabalho: o poder da autoeficácia e dos objetivos profissionais (Maio). Porto: Edições Politema.

Zetou, E., Kourtesis, T., Getsiou, K., Michalopoulou, M., \& Kioumourtzoglou, E. (2008). The Effect of Self-Modeling on Skill Learning and Self-Efficacy of Novice Female Beach Volleyball Players. The Online Journal of Sport Psychology.

Zetou, E., Vernadakis, N., Bebetsos, E., \& Makraki, E. (2012). The effect of self-talk in learning the volleyball service skill and self-efficacy improvement. Journal of Human Sport and Exercise, 7(4), 794-805. doi: doi.org/10.4100/jhse.2012.74.07 